Agro-Science Journal of Tropical Agriculture, Food, Environment and Extension Volume 17 Number 1 (January 2018) pp. 27 - 34

ISSN 1119-7455

\title{
ASSESSMENT OF UTILIZATION OF PRIMARY HEALTH CARE SERVICES AMONG SETTLED FULANI AGROPASTORALISTS IN OGUN STATE, NIGERIA
}

\author{
${ }^{* 1}$ Alarima C.I. and ${ }^{2}$ Obikwelu F.E. \\ ${ }^{1}$ Department of Agricultural Extension \& Rural Development, \\ Federal University of Agriculture, PMB 2240, Abeokuta, Ogun State, Nigeria \\ ${ }^{2}$ Graduate School of Agriculture, Kindai University, 3327-204 Nakamachi, Nara 631-8505, Japan \\ *Corresponding author's email: corneliusalarima@yahoo.com
}

\begin{abstract}
Utilization of primary health care services among settled Fulani agro-pastoralists in Ogun State was assessed in this study. Sixty (60) respondents were purposefully selected and interviewed using an interview guide. The data obtained were analyzed using descriptive and inferential statistics. The study revealed that the mean age of the respondents was $35.82,68.3 \%$ of the respondents were females and majority (80.0\%) of the respondents have no formal education. The results showed that friends and relatives were the main sources of information on primary health care services. About $90.0 \%$ of the respondents had positive attitude towards the use of primary healthcare services. The study also revealed that respondents visits primary health facility for pharmacy/dispensary (95.0\%), maternity (98.3\%) and vaccination/immunization (86.7\%). The result of the study revealed that the most pressing constraint faced by the agro-pastoralists was the distance of health facility from their settlement. Regression analysis showed that income, distance from home to health care center, information, attitude and constraints face influenced the utilization of primary healthcare services among the respondents. The study recommends that government should build health centres close to the agro-pastoralists to reduce the cost of medical services accessed by the pastoralists.
\end{abstract}

Key words: Fulani, healthcare, Ogun State, pastoralist, utilization

\section{INTRODUCTION}

There are about 50-100 million nomad/semi-nomad pastoralists in the developing world (Omar, 1992). Over $60 \%$ of these populations live in Africa (Sheik-Mohamed and Velema, 1999), with about 10 million found in Nigeria (Islam, 2001). The Nigerian pastoralists are made up of various ethnic groups such as Kenembu, Buduma, Bodawi, Shuwa-Arab, Koyo, Manga, Fulbe, Borobro among others. The largest group of pastoralists is the Fulbe or Fulani that constitute about $95 \%$ of the nomadic herders in Nigeria (Fabosoro, 2006). They tend to have among themselves similar social, economic and political characteristics and problems that delineate them from their sedentary neighbours. The Fulanis in Nigeria are mixed among Hausas in the northern part of the country and are the custodian of the nation's herd (Fabosoro, 2006). The Fulanis are among the most widely dispersed and culturally diverse peoples in Africa. Their immigration spanned several centuries; they traversed the West African savanna in small groups. They usually migrate from the mostly dry northern Nigeria and neighbouring countries to the wetter southern part, where they live in camps (Nweze, 2010). The climate change that led to drought in the Sahel region decades ago largely accounts for their movement from their origin to the northern guinea savanna of West Africa (Tonah, 2002). Pastoralism provides the best strategy to manage low net productivity, unpredictability and risk. As rainfall and temperature patterns result in marked spatial and temporal variations in livestock grazing resources, seasonal movements are essential for pastoralists (Nori, 2006). In Nigeria, the contribution of the Fulanis to the local food chain and national food security cannot be over emphasized (Abdikarim and Jolian, 1999). They hold over 90 per cent of the nation's livestock population. They are the major breeder of cattle, which is the main source of meat in Nigerian markets. Meat however, is the major source of animal protein consumed by many Nigerians because of its availability and comparative price to other animal protein products.

The Fulanis represent an important component of Nigerian economy which cannot be glossed over easily. In spite of the fact that pastoral Fulanis are responsible for the provision of animal meats in countries where they are found, their welfare (especially health) has been largely ignored by government due to inadequate resources since these groups are primarily nomadic (Ekpo et al., 2008). The health of nomadic pastoralists is 
influenced by some factors specific to their way of life. Nomads have the least access to any health services, and no satisfactory strategy has been devised to deliver proper health care to remote population (Sheik-Mohamed and Velema, 1999). Existing health care systems are in the hands of settled populations and nomads rarely have access to them due to cultural, political and economic obstacles (Sheik-Mohamed and Velema, 1999). The nomads are virtually ignored from the health services because it is usually in the hands of the settled population that do not relate well to them (Abdikarim and Joilan, 1999). Children of nomadic herdsmen are thought to be more at risk because of their early and continuous exposure to different kinds of animals (Nweze, 2010). Mace and Sear (1996) estimated a high maternal mortality rate (MMR) among the pastoralists. Infant mortality is higher among nomadic than among neighboring settled populations. Knowledge on everyday use of primary healthcare services by pastoralists' population is insufficient, little experience exists in providing primary health services to nomads, and only few evaluations of innovative services for nomadic communities have been performed (Swift et al., 1990). Yet, the identification of factors influencing the primary health service utilization patterns typical for nomads remains an additional challenge due to the scarce knowledge of nomad characteristics.

Therefore this study will open an avenue for further studies to know the essential barrier for the utilization of primary healthcare facilities by the pastoralists and also to know better ways to improving primary healthcare services utilization in the rural community. This study represents one of the few studies geared specifically towards understanding factors that are responsible for utilization of primary health services and implications in the nutritional and health status of the pastoralists in Ogun State. The broad objective of the study is to assess the utilization of primary healthcare services among settled Fulani agropastoralist in Ogun State, Nigeria. The specific objectives are to; examine the attitude of the settled Fulani agropastoralist towards the use of primary healthcare facilities; examine the constraint faced by the respondents in accessing primary healthcare services and assess the level of primary healthcare utilization among the settled Fulani agropastoralists.

\section{MATERIALS AND METHODS}

\section{Study Area and Sampling}

The study was conducted in Ogun State, Nigeria. The research was carried out in Abeokuta North, Yewa North and Odeda Local Government Areas of Ogun State. Abeokuta North Local Government has its headquarters situated at Akomoje. It has an area of $808 \mathrm{~km}^{2}$ and a population of 201,329 as at the 2006 census (NPC, 2006). The people of
Abeokuta North Local Government Area are predominantly farmers, most of who engage in subsistence and low-key commercial farming. There are also some who engage in livestock and fish farming. The major food crops of the area include cassava, cocoyam, plantain, maize and vegetables, while palm-produce and cocoa were the major cash crops in the study area. The Oyan dam, an important source of water to the cities of Lagos and Abeokuta, is located in this local government. Yewa North has its headquarters in Ayetoro, located on latitude $7^{\circ} 15^{\prime} \mathrm{N}$ and longitude $3^{\circ} 3^{\prime} \mathrm{E}$ in the deciduous derived savannah zone of Ogun State (Ojiako et al., 2014). It has the largest expanse of land with a size of 2,043.60 square hectares (Yewa North Local Government Commemorative brochure). It has a population of 181,826 (NPC, 2006) and is bounded in the West by Republic of Benin, in the South by Yewa South Local Government Area and in the North by Imeko/Afon Local Government Area. The major occupation of the people in these settlements is farming. The major crops grown include yam, tomato, beans, pepper, maize, vegetables and cassava. The main occupation in this area is trading and farming. The predominant economic activities in the study area informed migrants' dependence on land for shelter, income generation and trading, among others. Odeda Local Government has its headquarters at Odeda, located on the Abeokuta-Ibadan Interstate Road, which is about $20 \mathrm{~km}$ from the State capital, Abeokuta. Odeda is located on latitude $7^{\circ} 8^{\prime} \mathrm{N}$ to $7^{\circ} 30^{\prime}$ and a longitude $3^{\circ} 18^{\prime} \mathrm{E}$ to $3^{\circ} 37^{\prime}$ with a land area of 126,345 sq.km, and a population of 109,449 inhabitants representing $3.76 \%$ of the state population (NPC, 2006). The local government area enjoys tropical climate and double maximum of rainfall during April-July and SeptemberOctober. Average temperature is about $32^{\circ} \mathrm{C}$ but humidity can be as high as $95 \%$. The local government areas were selected based on the presence of herds and herdsmen as a result of availability of grassland, closeness to Oyo State with high number of pastoralist. The population of this study is the Fulani pastoralist in the local government areas. Twenty agropastoralists were purposefully selected from each local government to give a total of 60 respondents.

\section{Measures Sources of Information on Primary Healthcare Services}

This was measured at nominal level as community extension worker, health centre, radio, friends/relative, television and newspaper.

Attitude of the Settled Fulani Agropastoralist towards the Use of Primary Healthcare Services This was measured at interval level using 5-point Likert scale of Strongly Agree (SA), Agree (A), Undecided (U), Disagree (D), Strongly Disagree (SD). 
Constraint faced by the Settled Fulani Agropastoralist in Assessing Healthcare Services This was measured using 3-point rating scale format of Major Constraint, Minor Constraint, Not a Constraint.

\section{Utilization of Primary Healthcare Facility/Services by Agropastoralist}

This was measured using 3-point rating scale format as Always, Occasionally and Never.

\section{Data Collection and Data Analysis}

Interview schedule was used as instrument to collect primary data from the respondents. The primary data was obtained from the respondents on their socio-economic characteristics, sources of information and constraints they are faced with in assessing the primary healthcare services in their community. In order to achieve the objectives of the study the data collected was subjected to descriptive and inferential statistical analyses.

\section{RESULTS AND DISCUSSION \\ Socio-economic Characteristics of the Respondents}

The result of the study as shown in Table 1 revealed that the mean age of the respondents was 35.82 with more than half $(56.8 \%)$ of the respondents within the age group of 21-40 years. This implies that majority of the respondents are still within their active, reproductive age brackets. The study also revealed that most $(68.3 \%)$ of the respondents were female while $31.0 \%$ were male. This implies that majority of the respondents in the study area were female. Table 1 also reveals that majority $(95.0 \%)$ of the respondents are married. Marriage confers responsibility on individual. This assertion corroborates the report of Fakoya (2000) that marriage confers some level of responsibility and commitment on individuals who are married. The study revealed that all the respondents are Muslims. About $76.7 \%$ of the respondents are into trading and livestock rearing which agrees with the findings of Nori et al. (2005) that livestock represents the most important form of financial capital for pastoralists, both in terms of stock and flows. The study further revealed that majority $(80.0 \%)$ of the respondents had no formal education. Pastoralists are more concerned about their means of livelihood. According to Carney (1999), livelihoods of agropastoralist are capabilities, assets (including both social and material assets) and activities required for a means of living.

The study also revealed in Table 1 that all the respondents are non-indigenes of the study area. According to Tonah (2002) pastoralists immigration spanned several centuries, they traversed the West African savanna in small groups; their unit of migration is the compound family, reflecting the patrilineal system. The respondents sourced water mainly from stream/rivers. Poor source of water can cause illness such as cholera and diarrhea. This implies that respondents may likely be predispose to water borne disease such as cholera, diarrhea due to low availability of good, portable and accessible water in the area. About $85.0 \%$ of the respondents have no access to toilet hence they resulted in using the bush around their settlements as their toilet which predisposed them to other forms of risks such as snake bite. Health improvement comes from the proper use of sanitation facilities (Soetan, 2014). The mean household size of the study area is 7 persons with most of the families $(43.3 \%)$ having household size of 5-8 persons. The household size has implication for labour provision on the farm which increases farm productivity but it has the negative impact of causing overcrowding in the home. This agrees with Jones (2005) who reported that one of the causes of high incidence of malaria and other illnesses is environmental stress and overcrowding.

Table 1: Distribution of socio-economic characteristics of respondents $(n=60)$

\begin{tabular}{|c|c|c|c|}
\hline Variables & Definition & Measurement & Distribution \\
\hline Age & Actual age of respondents & Continuous & Average age $=35.82$ \\
\hline Sex & $\begin{array}{l}\text { Sex of the respondents as male or } \\
\text { female }\end{array}$ & Nominal & Male $(31.7 \%)$; Female $(68.3 \%)$ \\
\hline Marital Status & Married or Single & Nominal & Married (95.5); Single (4.5) \\
\hline Religion & Religious Affiliation & Nominal & Islam $(100 \%)$ \\
\hline Occupation & Occupation other than cattle rearing & Continuous & Trading $(76.7 \%)$; Farming $(16.7 \%)$ \\
\hline Educational Status & Highest education attainment & Nominal & $\begin{array}{l}\text { No formal Education }(80.0 \%) \text {; Quranic }(10 \%) \text {; } \\
\text { Primary }(6.7 \%) \text {; Secondary }(3.3 \%)\end{array}$ \\
\hline Native & Indigene or Non indigene & Nominal & Non-indigene $(100 \%)$ \\
\hline Water & Sources of water & Nominal & $\begin{array}{l}\text { Stream/river }(72.22 \%) \text {; Bore hole }(15.55 \%) \text {; } \\
\text { Well/deep well }(11.11 \%) \text {; Pipe borne water }(1.11 \%)\end{array}$ \\
\hline Toilet & Toilet facility & Nominal & Bush $(85.00 \%)$ \\
\hline Household size & Number of people in the household & Continuous & Average $=7$ persons \\
\hline Monthly income & Income realized every month & Continuous & Average $=\$ 45770.27$ \\
\hline $\begin{array}{l}\text { Cost of } \\
\text { Transportation }\end{array}$ & $\begin{array}{l}\text { Fare paid from residence to the nearest } \\
\text { health facility }\end{array}$ & Continuous & Average $=$ 612.24 \\
\hline
\end{tabular}


Table 2: Distribution of respondents according to sources of information on primary health care services $(n=60)$

\begin{tabular}{lll}
\hline S/n & $* *$ Sources of information & Percentage \\
\hline 1. & Radio & 18.3 \\
2. & Market & 51.7 \\
3. & Friends/Relatives & 80.0 \\
4. & Television & 8.3 \\
5. & Community Extension Worker & 58.3 \\
6. & Newspaper & 1.7 \\
\hline$* *$ Multiple responses provided &
\end{tabular}

Table 1 also reveal that the mean monthly income of respondents was $45,770.00$ which is above the Nigeria recommended minimum wage of 18000 . This shows that the purchasing power of the respondents is high in the study area. The income rate of an individual has a positive impact on the use of health care services (Soetan, 2014). This study also that the mean distance of $2.38 \mathrm{~km}$ is covered from settlements to primary health centre. Majority of the respondents cover between $0.5-4.0$ $\mathrm{km}$ from their settlements to access the primary health centre. This implies that majority of the respondents access the primary health centre at a long distance bearing in mind that respondent are always on the move with their animals searching for food and water resulting in coverage of additional distance before accessing health care service. The study also revealed that respondent spent average of $\$ 612$ on transportation on any occasion of visiting primary health centre closest to them. This implies that majority of the respondents spends more on transport due to inability of primary health centres located in the communities they live. Transport and distance to the nearest healthcare facility are factors that have been reported to influence the use of services (Andersen, 1995).

\section{Sources of Information on Primary Healthcare Services}

The results in Table 2 show that friends and relatives are the main sources of information available to respondents on primary health care services. This may not be far from the fact that most pastoralists leave a communal life style with ample opportunity to share information. The results further showed that respondent get information on primary health care services from community extension officers in their area. Community extension officers visit farmers with information on innovations in agriculture and health whenever information is available. Other sources of information included radio and television. Radio is a hand-held electronic device used by pastoralists as a source of entertainment since radio is affordable and do not rely solely on electricity. With dry cell batteries, pastoralists are able to use their radio conveniently.

\section{Attitude of the Settled Fulani Agropastoralist Towards the Use of Primary Healthcare Services}

The result as shown in Table 3 revealed that $90.0 \%$ of the respondents with the score range of 46-75 (mean $=48.12)$ had positive attitude towards the use of primary healthcare services. Health Belief Model (HBM) revealed that an individual's access to and use of health service is considered to be a function of the individual's attitude. Attitude of an individual to health service is one of the key determinants of health service utilization. Positive attitude enhance the utilization of health care services by the agropastoralists. This finding agrees with Andersen (1995) who posited that an individual who has positive attitude towards health service utilizes health service than an individual who has a negative attitude towards health service.

\section{Utilization of Primary Healthcare Services by the Settled Fulani Agropastoralist}

The results of the study as shown in Table 4 reveal that the mean utilization score among the respondents is 18.98 . The results also showed that majority of the respondents who made use of health facilities visit occasionally. This implies that majority of the respondents occasionally utilize the primary healthcare services. This was corroborated by Omotayo et al. (2005) who reported that most of pastoral Fulani utilize alternative healthcare services provided mainly by traditional medicine men, some patronize primary health care centres and some privately owned.

\section{Types of Healthcare Services Used by the Settled Fulani Agropastoralist}

The results of the study (Table 5) show that respondents' visits primary health centers for maternity. It was further revealed that respondents also visit Pharmacy/dispensary for medicine. This may be due to the fact that most people in local areas believe more in self-medication rather than visiting the health care institutions. The result also showed that most of the respondents visit primary health centers for routine vaccination/immunization of their children. This implies that respondents only visit primary health care centres when they were ill, during pregnancy and for collection of drugs.

\section{Constraint Faced by the Settled Fulani Agropastoralist in Assessing Healthcare Services}

The results of the study (Table 6) reveal that the greatest constraint faced by the agropastoralists was the distance of health facility from their settlement. This was followed by the expensive cost of health services they required. Others are inability to understand officers' language by pastoralists and vis-à-vis poor reception/performance of the attendant and 
inadequate staff/personnel. However, regardless of the constraints faced by the agropastoralists, they visit the healthcare services. This corroborates the findings of Omotayo et al. (2005) that Fulani makes use of modern healthcare services as over $90 \%$ of them indicate that they attended hospitals when they were ill.

\section{Determinants of Utilization of Primary Healthcare Services by the Settled Fulani Agropastoralists}

As reported by Dansabo and Muhammad (2014), the utilization of health care facility is subject to many factors which include educational status, cost of services, location of facilities, poor knowledge of pregnancy and health facilities, age, social support, cultural beliefs and practices, religious beliefs and practices. The result of the study as shown in Table 7 revealed that sex of respondents influences their use of primary health service. Most of the respondents are female, who bears the children with more demand for health services for themselves and their children especially maternity service. Mace and Sear (1996) estimated the maternal mortality rate among the pastoralists in Kenya at 599 per 100000 births. Although male agropastoralists were more infected than female (Anosike et al., 2005), discussions with the respondent revealed that most men sent their wives to help them buy medicines from stores since they are always busy with their animals. In addition, the result showed a significant relationship between marital status and utilization of primary healthcare services by the settled Fulani agropastoralists. This may not be far from the fact that most of the respondents are married and are responsible for taking care of their families. There is therefore a need for them to seek for health services for their family members. Nweze (2010) reported that the children of nomads are exposed to a variety of risks and infections and hence need for medical attention. Sheik-Mohamed and Velema (1999) also revealed that there is higher infant mortality among nomadic when compared to neighbouring host populations. The result further showed a significant relationship between income and utilization of primary healthcare services by the settled Fulani agropastoralists. This is expected because of the cost of services they may require. Since there is no health insurance policy for the respondents, there may be need for them to pay for services provided for them. According to Akogun et al. (2012), the government programmes in Nigeria to Roll Back Malaria for instance is yet to be felt by the nomadic Fulanis. Abdikarim and Joilan (1999) also reported that nomads are virtually ignored from the free health services because it is usually in the hands of the host populations. This implies that those with higher income may tend to seek for medical attention when compared to those with no means of paying for the services they required.

Table 3: Distribution of the attitude of the respondents towards the use of primary healthcare services $(n=60)$

\begin{tabular}{|c|c|c|c|c|c|c|c|c|}
\hline $\mathrm{S} / \mathrm{n}$ & Attitudinal Statement & SA & A & $\mathrm{U}$ & $\mathrm{D}$ & SD & Mean & SD \\
\hline 1. & Primary healthcare services is reliable for treatment whenever we visit & 45.0 & 55.0 & - & - & - & 4.45 & 0.502 \\
\hline 2. & $\begin{array}{l}\text { There are very few personnel at the prim } \\
\text { ary health centre to attend to the patient }\end{array}$ & 5.0 & 33.3 & 1.7 & 350.7 & 3.3 & 2.80 & 1.102 \\
\hline 3. & Primary health care personnel are not well trained & - & 1.7 & 10.0 & 80.0 & 8.3 & 2.05 & 0.502 \\
\hline 4. & $\begin{array}{l}\text { Primary health care personnel attend } \\
\text { to other tribe before attending to the Agropastoralists' }\end{array}$ & - & 1.7 & 75.0 & 21.7 & - & 1.83 & 0.526 \\
\hline 5. & Primary health centre is always crowded & 5.0 & 45.0 & 3.3 & 46.7 & - & 3.08 & 1.062 \\
\hline 6. & $\begin{array}{l}\text { Primary healthcare services improves our knowledge about other new } \\
\text { diseases and encourages us to eat healthy foods }\end{array}$ & 8.3 & 91.7 & - & - & - & 4.08 & 0.279 \\
\hline 7 & Primary health care services help prevent the outbreak of diseases & 10.0 & 91.7 & - & - & - & 4.10 & 0.303 \\
\hline 8. & Primary healthcare services improve Agropastoralists' health & 5.0 & 95.0 & - & - & - & 4.05 & 0.220 \\
\hline 9. & $\begin{array}{l}\text { Availability of primary health care services is a way of providing } \\
\text { social infrastructure }\end{array}$ & 8.3 & 88.3 & 3.3 & - & - & 4.05 & 0.341 \\
\hline 10. & Drugs supplied to the primary health centres are not reliable & - & 1.7 & 1.7 & 471.7 & 25.0 & 1.80 & 0.546 \\
\hline 11. & $\begin{array}{l}\text { The community health extension worker changed our perception about } \\
\text { health care services. }\end{array}$ & 3.3 & 91.7 & - & 3.3 & - & 3.98 & 0.431 \\
\hline 12. & Self medication is preferred to visiting primary health care services & 1.7 & 11.7 & 5.0 & 71.7 & 10.0 & 2.23 & 0.851 \\
\hline 13. & $\begin{array}{l}\text { Traditional medicine works better than primary health care centre } \\
\text { drugs }\end{array}$ & - & 8.3 & 31.7 & 58.3 & 1.7 & 2.47 & 0.676 \\
\hline 14. & Traditional medicine is easily accessible and cheap & 3.3 & 93.3 & - & 1.7 & 1.7 & 3.95 & 0.502 \\
\hline 15. & Primary health services are established for political reasons & 6.7 & 45.0 & 11.7 & 33.3 & 3.3 & 3.18 & 1.081 \\
\hline
\end{tabular}


Table 4: Distribution of utilization of primary healthcare services by the respondents $(n=60)$

\begin{tabular}{|c|c|c|c|c|c|c|}
\hline $\mathrm{s} / \mathrm{n}$ & Utilization & Always & $\begin{array}{l}\text { Occa- } \\
\text { sionally }\end{array}$ & Never & Mean & SD \\
\hline 1. & I make use of primary health care services? & 15.0 & 83.3 & 1.7 & 2.13 & 0.389 \\
\hline 2. & How often do you visit primary health care centers? & 3.3 & 95 & 1.7 & 2.02 & 0.225 \\
\hline 3. & I experience problem when I want to use the primary health care services? & 1.7 & 50.0 & 48.3 & 1.53 & 0.536 \\
\hline 4. & I leave health centre better than I went there? & 70.0 & 28.3 & 1.7 & 2.68 & 0.504 \\
\hline 5. & $\begin{array}{l}\text { Apart from treatment, I benefit other things from the primary healthcare } \\
\text { services? }\end{array}$ & 6.7 & 75.0 & 18.3 & 1.88 & 0.490 \\
\hline 6. & I visit primary health centres for medical checkup? & & 78.3 & 21.7 & 1.78 & 0.415 \\
\hline 7. & I give self medication when ill rather than visit primary health centres? & 3.3 & 46.7 & 50.0 & 1.53 & 0.566 \\
\hline 8. & How often do you visit traditional medicine men? & 1.7 & 70.0 & 28.3 & 1.73 & 0.482 \\
\hline 9. & $\begin{array}{l}\text { Primary healthcare services is visited by the female during and after } \\
\text { pregnancy }\end{array}$ & 45.0 & 53.3 & 1.7 & 2.43 & 0.533 \\
\hline 10. & Females patronize local mid-wifery? & 1.7 & 21.7 & 76.7 & 1.25 & 0.474 \\
\hline
\end{tabular}

Table 5: Types of healthcare services used by the respondents $(n=60)$

\begin{tabular}{llcc}
\hline S/n & Services & Yes $(\%)$ & Rank \\
\hline 1. & Counseling & 65.0 & $5^{\text {th }}$ \\
2. & Maternity & 98.3 & $1^{\text {st }}$ \\
3. & Laboratories & 25.0 & $6^{\text {th }}$ \\
4. & Test on HIV/Aids & 21.7 & $7^{\text {th }}$ \\
5. & Adult care & 86.7 & $3^{\text {rd }}$ \\
6. & Donation of Blood & 1.7 & $10^{\text {th }}$ \\
7. & Pharmacy/dispensary & 95.0 & $2^{\text {nd }}$ \\
8. & Family planning & 18.3 & $8^{\text {th }}$ \\
9. & Vaccination/Immunization & 86.7 & $3^{\text {rd }}$ \\
10. & Use of Ambulance/Emergency & 3.3 & $9^{\text {th }}$ \\
\hline
\end{tabular}

Table 6: Distribution of constraint faced by the respondents in assessing primary healthcare services $(n=60)$

\begin{tabular}{|c|c|c|c|c|}
\hline $\mathrm{S} / \mathrm{n}$ & Constraints & $\operatorname{Mac}(\%)$ & $\operatorname{Mic}(\%)$ & Rank \\
\hline 1. & Inability to understand health officers' language & 1.7 & 98.3 & $3^{\text {rd }}$ \\
\hline 2. & It is expensive & 20.0 & 80.0 & $2^{\text {nd }}$ \\
\hline 3. & Inadequate staff/personnel & 5.0 & 95.0 & $5^{\text {th }}$ \\
\hline 4. & It is far away from my settlement & 66.7 & 33.3 & $1^{\text {st }}$ \\
\hline 5. & Health care centers don't open regularly & 0.0 & 100 & $6^{\text {th }}$ \\
\hline 6. & Poor performance of the attendant & 1.7 & $59(98.3)$ & $3^{\text {rd }}$ \\
\hline 7. & I don't like taking drugs & 0.0 & 100 & $6^{\text {th }}$ \\
\hline 8. & Not aware of healthcare service & 0.0 & 100 & $6^{\text {th }}$ \\
\hline 9. & $\begin{array}{l}\text { Whenever we visit the health centres, treatment, drugs and } \\
\text { other health facilities are usually not available }\end{array}$ & 0.0 & 100 & $6^{\text {th }}$ \\
\hline 10. & Drugs collected from health centres are slow in action. & 0.0 & 100 & $6^{\text {th }}$ \\
\hline
\end{tabular}

As expected, there was a significant relationship between distance from home to health care center and utilization. With poor road network and lack of commercial transportation system in place, pastoralists trek long distance to the nearest health care center. The result further showed that access to information was significantly related to utilization of primary healthcare services by the settled Fulani agropastoralists. This implies that the more they have access to information the more they know about health care facilities and use these facilities. Jombo et al. (2010) reported that lack of information due to illiteracy among pastoralist was a major cause of infestation. With adequate formation on the facilities and service available in the health care center, utilization by pastoralists 11 be enhanced. The study also revealed that attitude of settled Fulani agropastoralists was significantly related to their utilization of primary healthcare services. With positive attitude towards health care services, they will use the facilities available to them and seek for medical attention if available. It should be noted that the provision of health services does not translate to utilization. But positive attitude as reported in this study, determines utilization. The study revealed a significant relationship between constraints face by settled Fulani agropastoralists and utilization of primary healthcare services. These ranged from non-availability of required drugs, relationship with health care personnel, cost of drugs and other personal factors among the pastoralists. 
Table 7: Regression analysis showing determinants of utilization of primary healthcare services by the respondents $(n=60)$

\begin{tabular}{lccccc}
\hline Variables & Coef & Std. Err. & $\mathrm{T}$ & $\mathrm{P}>\mathrm{t}$ & [95\% Conf. Interval] \\
\hline Constraints & -0.086 & 0.075 & -1.150 & 0.252 & -0.235 \\
Attitude & 0.139 & 0.052 & 2.670 & 0.008 & 0.036 \\
Information & 0.367 & 0.179 & 2.050 & 0.042 & 0.014 \\
Age & 0.027 & 0.012 & 2.310 & 0.022 & 0.004 \\
Sex & 0.652 & 0.314 & 2.070 & 0.040 & 0.031 \\
Marital status & 0.830 & 0.609 & 1.360 & 0.175 & 0.373 \\
Household size & 0.092 & 0.037 & 2.500 & 0.013 & 0.165 \\
Income & 0.000 & 0.000 & 2.900 & 0.004 & 0.000 \\
Distance & -0.221 & 0.079 & -2.790 & 0.006 & -0.378 \\
Cost of transportation & 0.000 & 0.000 & 1.280 & 0.201 & 0.000 \\
Constant & 6.445 & 3.063 & 2.100 & 0.037 & 0.399 \\
\hline
\end{tabular}

\section{CONCLUSIONS}

This study revealed that settled Fulani agropastoralists had positive attitude to primary health care services but the services are not easily accessible to them at their settlements. Major constraint limiting the use of primary health care services was the distance of health facility away from their settlement and the expensive cost of health services they required. The study showed that income, distance from home to health care center, information on primary health care services, attitude and constraints faced by the agropastoralists influenced the utilization of primary healthcare services among the respondents. Based on the findings of this study, the following recommendations are suggested to improve the utilization of primary health care services by the settled Fulani agropastoralist.

1 Government should build primary health centers close to the settled pastoralists. Also mobile clinic should be provided for those moving around with their herd.

2 State government and all stakeholders involved in providing primary healthcare services at the local level should improve on the level of awareness and enlightenment of the pastoralist on the importance and availability of health care services.

\section{REFERENCES}

Abdikarim S. and Jolian P.V. (1999). Where health care has no access; the nomadic population of SubSahara Africa. Trop. Med. Int., 4 (10), 677-770

Akogun O.B. Gundiri M.A. Badaki J.A. Njobdi S.Y. Adesina A.A. and Ogundahunsi, O.T. (2012). Febrile illness experience among Nigerian nomads. International Journal for Equity in Health, 11, 5-14
Andersen R.M. (1995). Revisiting the behavioral model and access to medical care: does it matter? Journal of Health and Social Behaviour, 36 (2), 1-10

Anosike J.C. Dozie I.N.S. Onwuliri C.O.E. Nwoke B.E.B. and Onwuliri V.A. (2005). Prevalence of mansonella perstans infections among the nomadic Fulanis of northern Nigeria. Ann Agric Environ Med, 12, 35-39

Carney D. (1999). Sustainable Rural Livelihoods. What difference can we make? DFID, London

Dansabo M.T. and Muhammad B.S. (2014). Factors affecting health and illness behaviour in Nigeria. Global Journal of Applied Management and Social Sciences, 7, 89-96

Ekpo U.F.. Omotayo A.M. and Dipeolu M.A. (2008). Sedentism and malnutrition among nomadic Fulani children in southwestern Nigeria. African Journal of Food, Agriculture, Nutrition and Development, 9 (1), 536-549

Fabusoro E. (2006). Property Rights, Access to Natural Resources and Livelihood Security among Settled Fulani Agro-Pastoralists in Southwestern Nigeria', Research Report for International Foundation For Science, Sweden/United Nations University Institute of Advanced Studies, Yokohama Japan, Research Grant No. P/3735-1, under the Agriculture For Peace in Africa Split Fellowship Programme

Fakoya E.O. (2000). Farmers' Use of Sustainable Land Management Practices Ondo State, Nigeria. Unpublished PhD Thesis, Department of Agricultural Extension \& Rural Development, University of Ibadan pp 160

Islam I. (2001). From nomadism to sedentarism : An analysis of development constraints and public issues in the socio economic transformation of the pastoral fulani of Nigeria. Accessed online at http://www.gamji.com/fulani1.htm on 27 June, 2017

Jombo G.T. Damen J.G. Safiyanu H. Odey F. and Mbaawuaga E.M. (2010). Human intestinal parasitism, potable water availability and methods of sewage disposal among nomadic Fulanis in Kuraje rural settlement of Zamfara state. Asian Pacific Journal of Tropical Medicine, 3 (6), 491-493 
Mace R. and Sear R. (1996). Maternal mortality in a Kenyan pastoralist population. International Journal of Gynaecology \& Obstetrics, 54, 137-141

NPC (2006). Population and housing census: Enumerators manual. National Population Commission (NPC), Federal Republic of Nigeria, pp: $1-16$

Nori M. (2006). Milking drylands: the marketing of camel milk in northeast Somalia. Nomadic Peoples 10 (1), 9-28

Nweze E.I. (2010). Dermatophytosis among children of Fulani/Hausa herdsmen living in southeastern Nigeria. Rev Iberoam Micol., 27 (4), 191-194

Ojiako A., Idowu O. and Ogbukwa C. (2014). Determinant of loan repayment behaviour of smallholder cooperative farmers in Yewa North Local Government area of Ogun State, Nigeria. Journal of Economic and Sustainable Development, 5 (16), 144-153

Omar M.A., (1992). Les nomads ont droit, eux aussi,a des services de sante. Forum mondial de la sante 13, 336-339

Omotayo A.M., Dipeolu M.A., and Ekpo U.F., (2005). Health consequences of lifestyle changes among pastoralists in South West, Nigeria. A research report submitted to Wellcome Trust and the University of Agriculture, Abeokuta
Sheik-Mohammed A., and Velema J.P. (1999). Where health care has no access: the nomadic populations of sub-Saharan Africa. Tropical medicine and international health, 4, 695-707

Soetan T.J. (2014). Utilization of Community-integrated Management of Childhood Illness among Rural Nursing Mothers in Ogun State, Nigeria. MSc thesis, Federal University of Agriculture, Abeokuta

Swift J., Toulmin C., and Chatting S. (1990). Providing services for nomadic people- A review of the literature and annontated bibliography. In: UNICEF staff working papers number 8, UNICEF, New York

Tonah S. (2002). Fulani pastoral migration, sedentary farmers and conflict in the middle belt of Ghana. Paper presented to the national conference on livelihood and migration, ISSER, University of Ghana, Legion Yewa North Local Government. Commemorative brochure of the official working visit of the governor of Ogun State to Yewa North Local Government; 2005 